\title{
Research on the Motivation and Effect of Ningbo Bank's Convertible Bond Financing
}

\author{
Liangchen Zhang ${ }^{1, *}$ Xiaobing Fang ${ }^{1}$ \\ ${ }^{1}$ School of Accounting, Xinhua College of Sun Yat-sen University, Dongguan, Guangdong 523133, China \\ ${ }^{*}$ Corresponding author. Email: zlcchair@163.com
}

\begin{abstract}
In recent years, due to the slowdown in market economic growth, the strengthening of capital flow supervision, and the rise in credit risk, China commercial banks have seen a downward trend in asset quality and capital adequacy ratios. Increasingly stringent regulatory requirements have also made capital adequacy ratios as an important assessment standard. As the profitability of some small and medium-sized banks is worrying, the space for internal capital replenishment such as traditional profit conversion and dividend conversion is gradually reduced. External sources such as convertible bonds have become the first choice for bank financing. Although commercial banks have begun to use convertible bond financing as the main direction of replenishing capital, issues such as the uncertainty of issuance and conversion, the large issuance scale, and the low stock price, and the difficulty of conversion, are still worth noting. This article will take the first china city commercial bank convertible bond "Ningbo bank Convertible Bond" as an example, study the process and effects of its issuance, and provide suggestions for listed state-owned and city commercial banks with convertible bond financing.
\end{abstract}

Keywords: Convertible bonds, Bank of Ningbo, Convertible bond financing, Financing effect.

\section{INTRODUCTION}

With the decline in the overall economic situation, the urban commercial asset allocation of the bank's capital adequacy decline and the continued implementation of the financial degradation leverage, which makes the bank's capital supplementation and more urgently introduced the refinancing program, and the issuance of transfer bonds become a universal effective refinancing program. Convertible bonds as a financial derivative product, itself has certain equity and option characteristics, commercial banks have relatively low cost by convertible bonds and direct equity financing, and the option characteristics can also continue the equity dilution effect. At the same time, share capital is increased in order to meet the regulatory requirements.

Bank of Ningbo city as a commercial bank was established on April 10, 1997. In May 2006, it introduced an overseas strategic investor Overseas-Chinese Banking Corporation of Singapore. On July 19, 2007, it was listed on the
Shenzhen Stock Exchange; after listed, a number of fundraising is carried out to supplement the company's core capital. 
Table 1. Statistics of Bank of Ningbo's equity fundraising (100 million yuan)

\begin{tabular}{|l|l|c|c|}
\hline Publish time & \multicolumn{1}{|c|}{ Fundraising method } & $\begin{array}{c}\text { Amount of } \\
\text { funds } \\
\text { raised }\end{array}$ & $\begin{array}{c}\text { Net } \\
\text { fundraising }\end{array}$ \\
\hline 2010 & Non-public offering of shares & 439474.50 & 437674.50 \\
\hline 2014 & Non-public offering of shares & 309276.65 & 307651.15 \\
\hline 2015 & $\begin{array}{l}\text { Non-public issuance of } \\
\text { preferred shares }\end{array}$ & 485000.00 & 482469.12 \\
\hline 2017 & Issuance of convertible bonds & 1000000.00 & 998107.00 \\
\hline
\end{tabular}

a Source: Announcement on the public offering of A-share convertible corporate bonds by Bank of Ningbo

It can be seen from "Table 1" that the Bank of Ningbo's equity fundraising statistics shows that the bank's non-public offering of stocks and preferred stocks raised amounts of 4,376,745,500 yuan, $3,076,511,500$ yuan, and 4,824,691,200 yuan, respectively. The equity financing period spans five years. The total equity funds raised is 12.2794777 million yuan. Compared with the 9981.07 million yuan of convertible bonds issued in December 2017, the issuance of convertible bonds takes a shorter time and a larger scale. If convertible bonds successful issued, the acquisition of capital will be more efficient than non-public offering of stocks or preferred stocks, and the conversion of convertible bonds can also regard as core capital. Therefore, the issuance of convertible bonds has become the optimal solution for Bank of Ningbo's financing.

\section{MOTIVATION ANALYSIS OF BANK OF NINGBO CONVERTIBLE BOND FINANCING}

\subsection{Demand for Credit Expansion}

It can be seen from "Table 2" that Bank of Ningbo's credit scale has continued to expand over the years, and the total amount of loans and advances issued by the Bank has continued to increase. In 2013, the bank's total loans amounted to RMB 171.190 billion. After five years of development, the loans and advances in 2017 was 346.2 billion yuan, an increase of nearly $102.33 \%$. The average growth rate of this indicator in the past five years has been maintained at about $18.95 \%$. The faster growth rate will bring greater capital pressure on itself. It is necessary to strengthen the supplement of capital to support the future development of the bank.

Table 2. The total amount of loans and advances issued by Bank of Ningbo from 2013 to 2017 (100 million yuan)

\begin{tabular}{|l|l|l|l|}
\hline Time & $\begin{array}{c}\text { Total loans and } \\
\text { advances issued }\end{array}$ & $\begin{array}{c}\text { Change in } \\
\text { amount }\end{array}$ & Increase \\
\hline 2017 & $3,462.01$ & 436.94 & $14.44 \%$ \\
\hline 2016 & $3,025.07$ & 468.18 & $18.31 \%$ \\
\hline 2015 & $2,556.89$ & 456.27 & $21.72 \%$ \\
\hline 2014 & $2,100.62$ & 388.72 & $22.71 \%$ \\
\hline 2013 & $1,711.90$ & 255.72 & $17.56 \%$ \\
\hline
\end{tabular}

With the strengthening of Bank of Ningbo's efforts to support the economy from development of personal consumption loans, the overall demand for funds has increased. From the perspective of supporting the real economy, Bank of Ningbo gives priority to supporting manufacturing and strategic emerging industries, focusing on private enterprises, and increasing the intensity and amount 
of credit. The bank's assets have extended general loans to corporate customers in 2017. The balance was 168.69 billion, an increase of 20.85 billion from the beginning of the year; it also vigorously expanded personal consumption loans and other loan businesses, and actively explored the local consumer credit market through precise positioning, and created consumption represented by "white-collar services". The scale of development reached 100 billion.

In terms of loan application process and use of client funds, Bank of Ningbo also pays more attention to retail business, intensively cultivates small and medium-sized enterprises, optimizes online loan application models and technical means, and launches "Online Quick Review Quick Loan 2.0", realizing mortgage loans. It adopts full online self-service application and automatic approval to improve the financing efficiency of small and micro enterprises, and through innovative loan renewal and repayment methods, continues to expand the business of "on-lending and financing" and "three-year loan", and also eases the repayment of loans due to small enterprises and the pressure of turnover, but the use of this model and technology has also brought a certain amount of pressure on the bank's loan collection.

\subsection{The Need to Maintain Capital Quality}

In the current banking regulations, the NPL ratio must not be higher than $5 \%$. The NPL ratio of Bank of Ningbo has been maintained at a low level. On the whole, the quality of assets of Bank of Ningbo is relatively high. From "Table 4", the bank's non-performing loan ratio in 2017 was $0.82 \%$, which was a decrease of $0.09 \%$ from the previous year. Good capital quality can achieve differentiation within market fluctuations.

Table 3. The total amount of loans and advances issued by Bank of Ningbo from 2012 to 2017 (100 million yuan)

\begin{tabular}{|l|l|l|}
\hline \multicolumn{1}{|c|}{ Time } & \multicolumn{1}{c|}{$\begin{array}{c}\text { Special mention loan } \\
\text { amount }\end{array}$} & \multicolumn{1}{c|}{ Proportion } \\
\hline 2017 & 23.50601 & $0.68 \%$ \\
\hline 2016 & 40.30597 & $1.33 \%$ \\
\hline 2015 & 45.27737 & $1.77 \%$ \\
\hline 2014 & 37.19403 & $1.77 \%$ \\
\hline 2013 & 18.09368 & $1.06 \%$ \\
\hline 2012 & 20.15806 & $1.38 \%$ \\
\hline
\end{tabular}

Table 4. Summary of non-performing loans amount from 2012 to 2017 of Bank of Ningbo (100 million yuan)

\begin{tabular}{|l|l|l|}
\hline \multicolumn{1}{|c|}{ Time } & \multicolumn{1}{|c|}{$\begin{array}{c}\text { Non-performing loan } \\
\text { amount }\end{array}$} & \multicolumn{1}{|c|}{ Proportion } \\
\hline 2017 & 28.38554 & $0.82 \%$ \\
\hline 2016 & 27.65469 & $0.91 \%$ \\
\hline 2015 & 23.61611 & $0.92 \%$ \\
\hline 2014 & 18.6283 & $0.89 \%$ \\
\hline 2013 & 15.25221 & $0.89 \%$ \\
\hline 2012 & 11.08584 & $0.76 \%$ a Source: Bank of Ningbo Annual Report 2012-2017 \\
\hline
\end{tabular}

However, as the whole, the non-performing loan ratio realized mainly by the expansion of loans issued by the bank has fallen. The change in the amount of non-performing loans from 2017 to 2017 "Table 4" shows that the indicator is increasing year by year, and the amount of non-performing loans in just six years has doubled by 1.5 times, while the ratio has only increased by $0.06 \%$. It can also be seen that the bank's overall loan scale is constantly expanding. To a certain extent, the expansion of non-performing loans will restrict the utilization of funds, making the bank have certain operational risks, and it is necessary to hedge the risks brought by non-performing loans by supplementing capital. 
Table 5. Summary of Provision Coverage Ratio of Bank of Ningbo from 2012 to 2017

\begin{tabular}{|l|l|l|}
\hline \multicolumn{1}{|c|}{ Time } & \multicolumn{1}{|c|}{$\begin{array}{c}\text { Provision coverage } \\
(\%)\end{array}$} & \multicolumn{1}{|c|}{ Increase (\%) } \\
\hline 2017 & 493.26 & 141.84 \\
\hline 2016 & 351.42 & 42.75 \\
\hline 2015 & 308.67 & 23.5 \\
\hline 2014 & 285.17 & 30.29 \\
\hline 2013 & 254.88 & -20.51 \\
\hline 2012 & 275.39 & 34.65 \\
\hline
\end{tabular}

The bank's provision coverage has been on an upward trend, from "Table 5", reaching $493.26 \%$ in 2017 , an increase of $141.84 \%$. It is far ahead of similar city commercial banks and maintains good control over loan risks, and has a high provision for risk losses. Combined with the bank's continuous increase in support for small, medium and micro enterprises and physical enterprises, it has expanded loan lines, but there is also Risk exposure, and by maintaining a high provision coverage ratio, it is helpful to enhance the ability to resist risks and maintain a better market performance level. However, a higher provision coverage ratio will also occupy a certain amount of capital, so the issuance can be transferred debt

Table 6. Capital structure of Bank of Ningbo from 2013 to 2017

\begin{tabular}{|l|l|l|}
\hline Project & Assets and liabilities & Equity/total assets \\
\hline 2013 & $94.48 \%$ & $5.52 \%$ \\
\hline 2014 & $93.83 \%$ & $6.17 \%$ \\
\hline 2015 & $93.71 \%$ & $6.29 \%$ \\
\hline 2016 & $94.31 \%$ & $5.69 \%$ \\
\hline 2017 & $94.46 \%$ & $5.54 \%$ \\
\hline
\end{tabular}

a Source: Bank of Ningbo Annual Report 2013-2017

Therefore, it is very appropriate for Bank of Ningbo to issue convertible bonds. In the later implementation of Ningbo bank's conversion of convertible bonds, long-term liabilities will be converted into ordinary shares and incorporated into shareholders' equity. It can also supplement the core Tier 1 capital required by bank supervision and enable the bank's internal equity, liability structure and capital structure. Improved, become more reasonable, and strengthen the vitality of the bank's own operations, which will help Bank of Ningbo to better in the face of fierce external competition and more complex internal and external environments, such as interest rate liberalization and continued upward currency market capital prices. Also more flexible to changes in the macroeconomic, rationally arranging assets, supplements internal capital and maintains asset quality is particularly critical.

\subsection{The Need to Improve the Debt Structure and Capital Structure}

It can be seen from the proportion of Bank of Ningbo's equity to total assets that the bank's equity proportion is relatively small. The changes in the equity structure from 2014 to 2017 show that the bank's shareholder equity proportion is decreasing. In 2017 , the proportion of shareholders' equity was only $5.54 \%, 0.63 \%$ from the highest figure of $6.17 \%$ in 2014. "Table 6" shows the change. optimizing the source of liabilities, controlling the cost of liabilities, and increasing the ability to resist risks.

\subsection{The Need to Optimize the Shareholding Structure}

Simple equity financing may dilute the original shareholder's shareholding ratio, while convertible bonds have both equity and debt properties. Compared with pure equity financing, the degree of dilution of the original shareholder's shareholding is relatively mild, making it easier to be issued. Also it is easy to sell online after the original shareholders' priority placement. 
Table 7. The equity structure of Bank of Ningbo before the issuance of convertible bonds

\begin{tabular}{|l|l|l|}
\hline \multicolumn{1}{|c|}{ Shareholder name } & \multicolumn{1}{|c|}{ Nature } & \multicolumn{1}{c|}{ Shareholding ratio (\%) } \\
\hline Ningbo Development Investment Group & State-owned legal person & 20 \\
\hline OCBC Bank Limited & Foreign legal person & 18.58 \\
\hline Youngor Group & Domestic non-state legal person & 11.64 \\
\hline Huamao Group & Domestic non-state legal person & 5.47 \\
\hline Ningbo Shanshan & Domestic non-state legal person & 3.91 \\
\hline Ningbo Fubon Holding Group & Domestic non-state legal person & 3.31 \\
\hline National Social Security Fund 101 Portfolio & $\begin{array}{l}\text { Funds, wealth management } \\
\text { products, etc. }\end{array}$ & 2.16 \\
\hline $\begin{array}{l}\text { Oversea-Chinese Banking Corporation } \\
\text { Limited (QFII) }\end{array}$ & Foreign legal person & 1.42 \\
\hline Central Huijin Asset Management & State-owned legal person & 1.38 \\
\hline Ningxing (Ningbo) Asset Management. & Domestic non-state legal person & 1.38 \\
\hline Total & & 69.25 \\
\hline
\end{tabular}

a Source: Prospectus for the public issuance of A-share convertible corporate bonds by Bank of Ningbo

Before Bank of Ningbo issued convertible bonds, it can be seen from "Table 6" most raised funds through non-public issuance of shares, and the subscriber was the original major shareholder, so the corresponding shareholding ratio was continuous. However, the issue of convertible bonds can effectively dilute the equity of major shareholders through the sale of the remaining part of the convertible bonds, and make the shareholder's equity structure more rational.

At the same time, according to the Regulations of the China Banking Regulatory Commission for the Implementation of Administrative Licensing Matters for Chinese-funded Commercial Banks, a single overseas financial institution and its affiliated parties controlled or jointly controlled as promoters or strategic investors may not invest in a single Chinese-funded commercial bank more than $20 \%$. However, date of the issuance of this prospectus, the bank's second largest shareholder, OCBC Bank and its QFII, have a total of $20 \%$ of the company's shares. There is a potential compliance risk to the company's equity structure. The issuance of OCBC can also restrict and dilute the shares of OCBC Bank, which will prevent the shareholding ratio of OCBC Bank from violating relevant laws and regulations. "Table 7" shows the data.

\subsection{Solving the Problem of Declining Asset Adequacy Ratio}

Capital Adequacy Ratio from "Table 8" shows the details of Ningbo's data compare with regulatory requirement. According to the regulatory requirements of the "Trial Measures for the Capital Management of Commercial Banks", the Tier 1 adequacy ratio and core Tier 1 capital adequacy ratio shall be greater than or equal to $8.5 \%$ and $7.5 \%$, respectively. However, the core Tier 1 capital ratio of Bank of Ningbo has been reduced since 2015 A decrease of $1.04 \%$. In 2016, the ratio fell further by $0.48 \%$. Although it rebounded in 2017 , it was still $8.61 \%$, which is only $1.11 \%$ away from the $7.5 \%$ required by the regulatory requirements. The Tier 1 core capital ratio of Bank of Ningbo has been declining since 2015. From $10.07 \%$ of the bank's Tier 1 capital adequacy ratio in 2014 to only $9.41 \%$ in 2017 , it is only $0.91 \%$ short of the regulatory red line. By looking through the data of other listed banks and city commercial banks, we can also find that the value of this category of Bank of Ningbo is still relatively low.

Table 8. Capital Adequacy Ratio of Bank of Ningbo from 2013 to 2017

\begin{tabular}{|l|l|l|l|}
\hline Project & $\begin{array}{c}\text { Capital } \\
\text { adequacy } \\
\text { ratio }(\%)\end{array}$ & $\begin{array}{c}\text { Tier } 1 \\
\text { capital } \\
\text { adequacy } \\
\text { ratio }(\%)\end{array}$ & $\begin{array}{c}\text { Core Tier } 1 \\
\text { capital } \\
\text { adequacy } \\
\text { ratio (\%) }\end{array}$ \\
\hline $\begin{array}{l}\text { Regulatory } \\
\text { requirements }\end{array}$ & $\geq 10.5 \%$ & $\geq 8.5$ & $\geq 8.5$ \\
\hline 2013 & 12.06 & 9.36 & 9.36 \\
\hline 2014 & 12.4 & 10.07 & 10.07 \\
\hline 2015 & 13.29 & 10.12 & 9.03 \\
\hline 2016 & 12.25 & 9.46 & 8.55 \\
\hline 2017 & 13.58 & 9.41 & $8.61 \quad$ a Source: Bank of Ningbo Annual Report 2013-2017
\end{tabular}


In summary, it can be found that Bank of Ningbo faces certain pressures due to the rapid growth of its capital scale. Although the central bank's Macro Prudential Assessment and capital pressure have relatively slowed the scale of Bank of Ningbo's development, the bank still needs to respond in a timely manner. The core capital is supplemented, and through the issuance of 10 billion convertible bonds, the capital pressure can be further eased in the later conversion of shares, and the regulatory red line requirements can be avoided, so as to avoid excessive attention and affect the sustainable development of the bank in the later period.

\section{ANALYSIS OF THE EFFECT OF THE CONVERTIBLE BOND FINANCING OF NINGBO BANK}

\subsection{Expanding the Scale of Credit and Expanding the Scale of Development}

From the perspective of Bank of Ningbo's total asset growth from 2013 to 2017 ("Table 9"), the growth rate of total assets is at a high level, with an average growth rate of $24.11 \%$, but there has been a significant decline in 2017. The reason is that it is in the L-shaped stage of the macro environment, the strong supervision and deleveraging of the supervisory authority, the banking industry as a whole has been greatly affected, and the overall scale of the industry has slowed down. However, the Bank of Ningbo financed through the issuance of convertible bonds. The total assets and credit scale have also been expanded.

Table 9. Changes in Bank of Ningbo Credit Scale from 2013 to 2019 (100 million yuan)

\begin{tabular}{|l|l|l|}
\hline Time & $\begin{array}{c}\text { Total loans and } \\
\text { advances issued }\end{array}$ & Growth rate (\%) \\
\hline 2013 & 1711.9 & 17.56 \\
\hline 2014 & 2100.62 & 22.71 \\
\hline 2015 & 2556.89 & 21.72 \\
\hline 2016 & 3025.07 & 18.31 \\
\hline 2017 & 3462.01 & 14.44 \\
\hline 2018 & 4290.87 & 23.94 \\
\hline 2019 & 5291.02 & 23.31 \\
\hline
\end{tabular}

Table 10. Changes in total assets of Bank of Ningbo from 2013 to 2019 (100 million yuan)

\begin{tabular}{|l|l|l|}
\hline Time & \multicolumn{1}{|c|}{ Total assets } & \multicolumn{1}{|c|}{ Growth rate (\%) } \\
\hline 2013 & $4,621.88$ & 23.73 \\
\hline 2014 & $5,541.12$ & 19.89 \\
\hline 2015 & $7,164.65$ & 29.3 \\
\hline 2016 & $8,850.20$ & 23.53 \\
\hline 2017 & $10,320.42$ & 16.61 \\
\hline 2018 & $11,164.23$ & $8.18 \%$ \\
\hline 2019 & $13,177.17$ & $18.03 \%$ \\
\hline
\end{tabular}

a Source: Bank of Ningbo Annual Report 2013-2019

From the issuance of convertible bonds by Bank of Ningbo in 2018 to the completion of the final equity conversion in 2019, the capital has been replenished, and its scope and ability to expand its business are also stronger. In 2019, the number of new outlets increased by 40 compared with the last year, and employees recruited increased to 3444 .
The growth rates of both are at the highest value of growth over the years. Judging from the ratio of the number of employees divided by the number of outlets of the bank, the ratio in 2019 was 45.86, an increase of $11.58 \%$ from the ratio of 41.10 in 2018 . "Table 11" shows the changes. 
Table 11. Summary of the number of employees and branch coverage of Bank of Ningbo from 2013 to 2019

\begin{tabular}{|l|l|l|l|}
\hline Time & $\begin{array}{c}\text { number of } \\
\text { workers } \\
\text { (people) }\end{array}$ & $\begin{array}{c}\text { Number of outlets } \\
\text { covered (a) }\end{array}$ & $\begin{array}{c}\text { Number of } \\
\text { employees/numb } \\
\text { er of outlets }\end{array}$ \\
\hline 2013 & 6323 & 210 & 30.11 \\
\hline 2014 & 7498 & 246 & 30.48 \\
\hline 2015 & 9619 & 285 & 33.75 \\
\hline 2016 & 11706 & 314 & 37.28 \\
\hline 2017 & 12317 & 317 & 38.85 \\
\hline 2018 & 13893 & 338 & 41.1 \\
\hline 2019 & 17337 & 378 & 45.86 \\
\hline
\end{tabular}

It can be seen that the Bank of Ningbo convertible bond financing has increased the number of outlets and the number of employees, expanded the market scale and market share, and provided help for larger-scale development in the future.

\subsection{Improving the Capital and Liability Structure to Achieve Long-term Development}

After the issue convertible bonds in 2017, the proportion of bonds payable in the debt structure of Bank of Ningbo in the total liabilities has increased by $4.05 \%$. The proportion of convertible bonds reached $25 \%$ by the end of the year, and bonds payable were gradually converted into shareholder equity. The number of convertible bonds has

Table 12. declined to a certain extent, but the three-phase financial bonds issued in 2018 and the Green bonds have also caused a certain increase in the proportion of bonds payable in 2018, but the increase is not large. In 2019, with the continuous conversion of Ningbank's convertible bonds, after $99.89 \%$ of convertible bonds were converted into equity, the proportion of bonds payable dropped to $17.49 \%$. "Table 12" shows the proportions.

Summary of Major Liabilities of Bank of Ningbo from 2015 to 2019(100 million yuan)

\begin{tabular}{|l|l|l|l|l|}
\hline \multicolumn{2}{|c|}{ project } & \multicolumn{1}{c|}{$\begin{array}{c}\text { Take } \\
\text { deposits }\end{array}$} & $\begin{array}{c}\text { Borrowed } \\
\text { funds }\end{array}$ & $\begin{array}{c}\text { Bonds } \\
\text { payable }\end{array}$ \\
\hline 2015 & Amount & 3556.85 & 202 & 1440.56 \\
\cline { 2 - 5 } & $\begin{array}{l}\text { Proportion } \\
(\%)\end{array}$ & $52.98 \%$ & $3.01 \%$ & $21.47 \%$ \\
\hline 2016 & Amount & 538.48 & 597.73 & 585.14 \\
\cline { 2 - 5 } & $\begin{array}{l}\text { Proportion } \\
(\%)\end{array}$ & $61.27 \%$ & $4.17 \%$ & $13.54 \%$ \\
\hline 2017 & Amount & 5652.53 & 946.06 & 1129.84 \\
\cline { 2 - 5 } & $\begin{array}{l}\text { Proportion } \\
(\%)\end{array}$ & $57.98 \%$ & $9.70 \%$ & $17.59 \%$ \\
\hline 2018 & Amount & 6467.21 & 539.43 & 2084.37 \\
\cline { 2 - 5 } & $\begin{array}{l}\text { Proportion } \\
(\%)\end{array}$ & $62.47 \%$ & $5.21 \%$ & $20.14 \%$ \\
\hline 2019 & Amount & 7792.24 & 359.62 & 2128.85 \\
\cline { 2 - 5 } & $\begin{array}{l}\text { Proportion } \\
(\%)\end{array}$ & $64.03 \%$ & $2.96 \%$ & $17.49 \%$ \\
\hline
\end{tabular}

Source: Bank of Ningbo 2015-2019 Annual Report

Generally speaking, the issuance of convertible bonds has optimized the liability structure of Bank of Ningbo. If the proportion of deposits is too low and short-term borrowing of funds is needed to support operations, banks can take advantage of long-term and stability through the issuance of convertible bonds. It can reduce the risk on the liability side and improve the profitability of the bank; and when the bank absorbs more deposits and issues financial bonds, the conversion of convertible bonds will enhance the bank's equity level and avoid excessive passive debt and operational instability. It is unstable and restrictive. At the same time, the occurrence of equity 
conversion has also reduced the interest payment cost of convertible bonds. When banks issue largescale financial bonds, they will reduce unnecessary interest payment pressure of the bank.

\subsection{Optimizing the Equity Structure and Encouraging Effective Operation}

"Table 13" shows the change of shareholder ratio after conversion. The issuance of the Bank's convertible bonds has been strongly diluted in the original united equity concentration, making the main shareholding share of shareholders to

Table 13. The top ten shareholders' shareholding table before and after the issuance of the Bank of Ningbo convertible bond maintain less than $20 \%$, the proportion of major private capital is more than $20 \%$, and the ratio of state-owned capital and overseas capital and private capital is also conducive to the company's marketoriented development. At the same time, the guild will work hard to operate enterprises, maximizing the benefits of corporate economic interests, and avoid triggering the sales behavior due to adverse performance. Through the expansion of business scale, the range of profitability and ability, the share price can be steadily rising, attracting investors as long-term shareholders.

\begin{tabular}{|l|l|l|l|}
\hline \multicolumn{1}{|c|}{ Shareholder } & $\begin{array}{c}\text { Shareholding ratio } \\
\text { before issuance }\end{array}$ & $\begin{array}{c}\text { Shareholding ratio after } \\
\text { conversion }\end{array}$ & Variation \\
\hline $\begin{array}{l}\text { Ningbo Development } \\
\text { Investment }\end{array}$ & $20 \%$ & $19.99 \%$ & $-0.01 \%$ \\
\hline OCBC Bank Limited & $18.58 \%$ & $18.58 \%$ & $0.00 \%$ \\
\hline Youngor Group & $11.64 \%$ & $14.15 \%$ & $2.51 \%$ \\
\hline Huamao Group & $5.47 \%$ & $3.91 \%$ & $-1.56 \%$ \\
\hline Ningbo Shanshan & $3.91 \%$ & $1.30 \%$ & $-2.61 \%$ \\
\hline $\begin{array}{l}\text { Ningbo Fubon Holding } \\
\text { Group }\end{array}$ & $3.31 \%$ & $\begin{array}{l}\text { Shareholding ratio after } \\
\text { before issuance }\end{array}$ & Variation \\
\hline $\begin{array}{l}\text { National Social Security } \\
\text { Fund 101 Portfolio }\end{array}$ & $2.16 \%$ & $2.47 \%$ & $-0.84 \%$ \\
\hline $\begin{array}{l}\text { Oversea-Chinese } \\
\text { Banking Corporation } \\
\text { Limited (QFII) }\end{array}$ & $1.42 \%$ & $1.42 \%$ & $-2.16 \%$ \\
\hline $\begin{array}{l}\text { Central Huijin Asset } \\
\text { Management }\end{array}$ & $1.38 \%$ & $1.24 \%$ & $0.00 \%$ \\
\hline $\begin{array}{l}\text { Ningxing (Ningbo) } \\
\text { Asset Management }\end{array}$ & $1.38 \%$ & $1.38 \%$ & $-0.14 \%$ \\
\hline $\begin{array}{l}\text { Hong Kong Securities } \\
\text { Clearing Company } \\
\text { Limited }\end{array}$ & $2.68 \%$ & $0.00 \%$ \\
\hline $\begin{array}{l}\text { Shareholding ratio of } \\
\text { the top ten shareholders }\end{array}$ & $69.25 \%$ & $67.12 \%$ & $-2.13 \%$ \\
\hline
\end{tabular}

Source: Prospectus for the public issuance of A-share convertible corporate bonds by Bank of Ningbo, 2019 annual report

\subsection{Meeting Regulatory Needs and Increasing Capital Adequacy Ratio}

The capital adequacy ratio is the bottom line of the bank's development and is of great significance. The bank attaches great importance to this indicator. It can be seen that the purpose of Ningbo Bank's issuance of convertible bonds is relatively straightforward, which is to achieve effective capital supplementation in the later stage of conversion taxation to meet regulatory requirements.

Table 14.

2015-2019 Capital Adequacy Ratio of Bank of Ningbo

\begin{tabular}{|l|l|l|l|}
\hline \multicolumn{1}{|c|}{ Project } & $\begin{array}{c}\text { Capital } \\
\text { adequacy ratio } \\
(\%)\end{array}$ & $\begin{array}{c}\text { Tier 1 capital } \\
\text { adequacy ratio } \\
(\%)\end{array}$ & $\begin{array}{c}\text { Core Tier 1 capital } \\
\text { adequacy ratio (\%) }\end{array}$ \\
\hline $\begin{array}{l}\text { Regulatory } \\
\text { requirements }\end{array}$ & $\geq 10.5 \%$ & $\geq 8.5$ & $\geq 7.5$ \\
\hline 2015 & 13.29 & 10.12 & 9.03 \\
\hline 2016 & 12.25 & 9.46 & 8.55 \\
\hline 2017 & 13.58 & 9.41 & 8.61 \\
\hline
\end{tabular}




\begin{tabular}{|l|l|l|l|}
\hline 2018 & 14.86 & 11.22 & 9.16 \\
\hline 2019 & 15.57 & 11.3 & 9.62 \\
\hline
\end{tabular}

In 2018, the bank's 10 billion convertible bonds issued by the bank achieved a $25 \%$ conversion, and this part of the convertible bonds was directly supplemented after conversion. In addition, profits continue to grow, and capital is further effectively supplemented. At the same time, the reason why the Tier 1 capital adequacy ratio has increased faster than the core Tier 1 capital adequacy ratio is because the bank completed the issuance of 10 billion yuan of preferred shares in 2018 , the capital constraint mechanism has been further strengthened, and the capital adequacy ratio has continued maintain a steady level.

Afterwards, the bank's core Tier 1 capital adequacy ratio increased by $0.46 \%$ in 2019 , which was higher than the $0.08 \%$ increase in Tier 1 capital adequacy ratio, mainly because price of Ningbo bank's convertible bonds touched the terms of compulsory redemption. The bank issued 14 redemption reminder announcements successively, speeding up investors' conversion behavior, and finally $99.81 \%$ of Ningbo bank's convertible bonds realized conversion, which greatly supplemented the bank's owner's equity. "Table 14" shows the ratios for comparison.

\subsection{Preventing Downside Risks in the Industry and Enhancing Its Own Profitability}

The convertible bonds issued by Bank of Ningbo in the first year and the second year are relatively low, at $0.2 \%$ and $0.4 \%$, respectively. Over time, although interest rates are in a stage of gradual increase, the rate of increase is relatively slow. If Ningbobank's convertible bonds are converted into shares in the first few years of interest payments, it can reduce the bank's overall financial costs. At the same time, the lower coupon rate of convertible bonds will also encourage holders to convert earlier. Dividends will also make its conversion price gradually drop, making investors inclined to convert, so that the bank faces relatively low debt pressure, and a larger scale of convertible bond fund raising can also make it better to carry out development of wealth management products to improve their own profitability.
In 2017 , the return on net assets of listed city commercial banks suddenly dropped from $13.99 \%$ to $10.96 \%$ in 2018 , indicating that the credit risk of the banking industry was in the exposure stage during this period, and the Bank issued 10 billion convertible bonds. The increase in capital sufficiency promoted capital adequacy, expanded the bank's loan scale and operating scale, achieved efficient use of funds, slowed down the indicator, and also reflected the bank's continued increase in profitability.

\section{RESEARCH ENLIGHTENMENT}

\subsection{Anticipating Risks When Banks Issue Convertible Bonds}

Convertible bonds are a complex financial derivative product. Issuance will be subject to strict supervision by the China Securities Regulatory Commission and related departments. The macroeconomic environment and operating conditions of the issuers themselves will affect the smooth issuance of convertible bonds. In this process, the issuer needs to consider the overall environment and choose an appropriate financing method. In addition, the issuance of bankable bonds has the characteristics of large scale and long time. The large scale of issuance can enable them to obtain more financial support from the capital market. However, the issuance of convertible bonds is subject to various conditions. If the conversion is unsuccessful in the later period, the issuance of banks will face greater debt collection pressure.

Grasping a good timing of issuance is an important factor for the smooth issuance and conversion of bank convertible bonds. The main purpose of bank's issuance of convertible bonds is to form a debt-to-equity situation, so as to achieve the purpose of replenishing core Tier 1 capital in a timely manner. Therefore, it is very important to grasp the timing of the issuance. When a convertible bond is issued in a bear market, most investors will not have greater expectations of the market. At this time, the issuance of bank convertible bonds will affect its issuance price, and it is difficult to guarantee the short-term price. Obtaining greater growth, greatly prolonging the possibility of conversion time, making it impossible 
to achieve the purpose of issuance as soon as possible; and when convertible bonds are issued in the bull market, the stock price is relatively high, and there is bound to be a downward trend in the future, which will lead to the price of the stock. Higher than the actual price, when the conversion begins, the stock price will become unattractive and prompt investors to convert, which will cause greater uncertainty in the conversion and increase the issuer's financial risk.

Therefore, when issuing bank convertible bonds, the issuing bank should fully consider the market environment, choose a suitable issuance time, and predict market risks in advance. It is also necessary to reasonably formulate a convertible bond plan. By reasonably formulating the issuance clauses, establishing necessary mandatory downward amendment clauses and conditional resale clauses, it can also promote the realization of the bank's conversion of convertible bonds into equity.

\subsection{Leveraging the Advantages of Convertible Bond Financing}

Convertible bonds have certain advantages in China refinancing market. First, compared with preferred stocks, open maturity capital bonds and tier 2 capital bonds, convertible bonds can supplement core tier 1 capital after conversion. Stocks and bonds can only supplement other Tier 1 capital or Tier 2 capital, and the scope and quality of capital supplementation is relatively low. Therefore, convertible bond financing can make capital supplementation achieve significant effects, improve risk resistance, and meet regulatory requirements.

Second, the financing cost is low. The interest paid by the convertible bond before the conversion is significantly lower than that of the secondary capital bond and preferred stock. The coupon rate is usually low, often less than $1 \%$, which is conducive to reducing the capital cost of commercial banks. For example, the interest rate of Ningbo bank's convertible bonds in the first year is only $0.2 \%$, which is more advantageous than traditional financial bonds.

Third, the issuance of the convertible bond market is heating up. Due to the introduction of the new refinancing regulations, the issuance method and other regulations have been adjusted, and the traditional form of prepayment has been cancelled. The original fund purchase by investors has been changed to credit purchase, and at the same time The China Securities Regulatory Commission allows convertible bond financing not to be restricted by the 6 -month financing interval. In summary, the financing advantages of convertible bonds issued by banks qualified for listing are obvious.

\subsection{Improving Capital Creativity and Coordinating Endogenous and Exogenous Financing}

There are more ways of refinancing by commercial banks, and the external financing and internal financing channels are also expanding. But for banks, it is more important to improve their own capital creativity and increase with the supplement of retained earnings. The bank's own internal financing, which only relies on internal financing such as preferred stock issuance or external financing such as the issuance of convertible bonds, treats the symptoms rather than the root cause. Commercial banks should formulate their capital plans scientifically and effectively, and make necessary adjustments based on their internal operating conditions and changes in the external market environment to achieve effective management from asset scale to risk. At the same time, it is necessary to vigorously develop innovative businesses, shift business development to the direction of light assets, and expand low-risk businesses to improve its own risk control capabilities, reduce capital consumption, and achieve the expansion of endogenous financing.

In addition, China's banking industry is currently in an era of differentiated competition. The service concept of banks has shifted from the traditional "customer"-centric to the "user"-centric. The development direction of modern banks is beginning to emerge, from transaction banking to retail from banks to fintech banks, smart banks, and then to open banks and platform banks, China's banking industry is gradually exploring. However, under the complex market exploration and development investment, for example, banks find that endogenous financing and their own capital are difficult to support themselves. When development needs, you can strengthen your own external financing, increase the proportion of external financing in the total financing to enhance your own capital strength, and promote your own remodeling and development through the coordinated development of endogenous and 
external financing. This process also promotes improvement of capital creativity.

\section{CONCLUSION}

In China, the development of convertible bond market is relatively not long, and the relevant regulatory system is not yet complete. The issuers' design case reference and research on the number, scale, and relevant terms of issuance are still in developing stage compared to mature markets worldwide.

Commercial banks' issuance of convertible bonds for refinancing is not yet mature in the banking industry. The issuance of convertible bonds from Bank of Ningbo is based on the emergence of macroeconomic pressures and stricter supervision. The bank has made optimizations in terms of credit development, capital liabilities, regulatory requirements and risk resistance. It can be seen that the issuance of convertible bonds is of great significance to the refinancing needs of commercial banks.

In April 2021, the People's Bank of China and the China Banking Regulatory Commission issued the "Additional Supervision Regulations for Systemically Important Banks (Trial) (Draft for Comment)", which put forward higher regulatory capital requirements for banks included in D-SIBs, and D-SIBs requirements. The small and medium banks under the government will also face capital shortages. In the future, some joint stock banks and city commercial banks will generally face a tight core tier 1 capital adequacy ratio when the economic down. Although this regulation is currently in the process of soliciting opinions, when it is officially implemented, the author believes that it will catalyze the conversion of stock convertible bonds of most commercial banks, and will prompt more bank convertible bond issuance plans.

This article takes the successfully converted city commercial bank Ningbo bank convertible bond as the case, analyse the reasons for the issuance and the economic consequences after the issuance, willingly to provide a reference for commercial banks that choose convertible bond financing in the future.

\section{AUTHORS' CONTRIBUTIONS}

Liangchen Zhang was responsible for writing the manuscript and analysing data, and Xiaobing Fang contributed to revising and editing.

\section{REFERENCES}

[1] Xin Hou, Mengshan Xie, Yu Chen, The market constraint of bank capital tools increased - Empirical evidence based on or convertible bonds [J]. Management Modernization, 2019,39 (04): 1-4.

[2] Haicheng Yin. Capital dilemma and response measures of commercial banks under the new situation [J]. China Banking, 2019 (02): 4547.

[3] Li Feng Zhou, Danhua Luo. Advantages and Strategic Recommendations for Commercial Bank Cost Bonds [J]. China Banking, 2019 (03): 86-88.

[4] Wenhua Wang, XueZhi Qin, Xiang Zhang, Majun Zhang. Decontade of debt and debt subtraction characteristics or have exposed bonds and their pricing [J]. System Management Journal, 2020,29 (05): 895-904.

[5] Shuyuan Han, Wenting Huang. Problems and Policy Suggestions for Commercial Bank Cost Bond Supported Capital [J]. Western Finance, 2019 (11): 46-48.

[6] Ming Peng, Mengzhen Zhang. Analysis and Countermeasures of Commercial Bank Capital Supplement Tools [J]. Financial Crossing, 2020 (03): 68-75.

[7] Yizhen Yang, Sheng Duan.Study on the Capital Supplementary Channel and Path of Small and Medium Banks in Rural Areas [J]. Contemporary Rural Finance, 2021 (02): 5663. 